\title{
Scope of Action at the European Level
}

\author{
Brian Bercusson $\uparrow$
}

I. Executive Summary $\quad 62$

1. Strategies in the short-term $\quad 63$

2. Strategies in the medium-term $\quad 63$

3. Strategies for the long-term $\quad 64$

II. Introduction: The price of not remembering history is to repeat it 64

III. The ECJ invents a new EU law on collective action 66

1. Uncertain criteria for the legality of collective action 66

2. Horizontal direct effect against trade unions $\quad 67$

3. Unequal treatment of workers on grounds of nationality 68

$\begin{array}{ll}\text { 4. Violation of international labour law standards } & 68\end{array}$

5. Violation of the principle of subsidiarity $\quad 69$

6. A charter for "social dumping" $\quad 70$

$\begin{array}{ll}\text { 7. In sum... } & 70\end{array}$

IV. Scope of action at European level after the Lisbon Treaty 73

V. Strategies in the short-term

1. Legal form $\quad 73$

2. A Protocol $\quad 74$

3. Enhanced cooperation $\quad 74$

4. The "Schengen" model 74

5. A non-binding Social Declaration $\quad 74$

6. An interpretative instrument (inverse "opt-out") 75

$\begin{array}{ll}\text { 7. Content } & 75\end{array}$

8. An "anti-social dumping principle" against abuse of the exercise of economic freedoms

9. A non-regression clause

10. A more favourable treatment clause $\quad 77$

11. An interpretative framework for economic freedoms 78

a) A rebuttable presumption in favour of collective action 78

b) Interpreting "proportionality" in light of the acquis communautaire social 79

c) Human rights are not mere derogations from economic freedoms; rather the reverse

12. The Agency Workers Directive: Equal treatment of agency workers includes cross-border workers

VI. Strategies in the medium-term $\quad 80$

1. "Update" the "explanations" to the EU Charter 80

2. A standard social safeguard clause in directives $\quad 81$ 
3. Monitoring transposition of the Services Directive 81

4. Social impact assessments $\quad 81$

5. Operationalising the Lisbon Treaty's horizontal social clause 82

6. Revise the Posting Directive $\quad 82$

VII. Strategies for the long-term $\quad 83$

1. Revise Treaty provisions on economic freedoms 83

2. Revise the Treaty to prevent employers using economic freedoms against
trade unions taking collective action (horizontal direct effect)

3. Revise the subsidiarity principle to exclude EC competence to regulate
collective action

4. Reform the European Court of Justice 85

a) Structure of the ECJ $\quad 85$

b) Competences of the ECJ

c) Procedures of the ECJ 86

d) Composition of the ECJ 86

5. Reinforce international labour law in the Treaties 87

a) The European Social Charter $\quad 87$

b) ILO Conventions $\quad 87$

c) Interpreting "proportionality" in light of international labour law 87

$\begin{array}{lr}\text { VIII. Conclusion } & 88\end{array}$

1. National labour law $\quad 88$

2. The balance of power in the EU economy

3. The law on workers' collective action 89

4. Transnational collective action and EU law 89

\section{Executive Summary}

The paper begins with an analysis of the decisions of the European Court of Justice in Viking, Laval and Rüffert. The decisions are criticised as inventing an EU law on workers' collective action. This new law establishes uncertain criteria for the legality of collective action, introduces horizontal direct effect against trade unions, allows for unequal treatment of workers on grounds of nationality, violates international labour law standards, infringes the principle of subsidiarity and is tantamount to a charter for "social dumping". This new EU law is already being invoked by employers at national level to block otherwise lawful collective action. It poses a threat to the stability of national industrial relations systems and to European integration.

The paper then explores the scope for action at European level to address this new EU law created by the ECJ which was not envisaged when the Lisbon Treaty was proposed. It suggests short, medium and long-term strategies in the context of the Irish rejection of the Lisbon Treaty. 


\section{Strategies in the short-term}

In light of this new law, not foreseen by the Lisbon Treaty, Member States may now undertake a commitment to a stronger social dimension. Suggestions are made as to the legal form and the substantive content of such a commitment.

As to legal form: Some Member States could adopt a Protocol on a stronger social dimension as a condition to final ratification of the Lisbon Treaty. All Member States could agree to this Protocol binding only those Member States who accept the Protocol.

If at least 14 Member States agreed, in the course of ratifying the Lisbon Treaty, that they wanted stronger social provisions, the mechanism of enhanced cooperation (Article 43 TEU) allows this, leaving it open to other Member States to join later.

A "Social Schengen" agreement between an initially small number of Member States, which more may gradually join, could be adopted in the course of ratification of the Lisbon Treaty, eventually to be incorporated into the legal framework of the EU.

A commonly agreed "social declaration", though not legally binding, could have a future impact on the political agenda of the EU institutions.

An interpretative instrument could be attached to the ratification in the form of an "opt-out" opposite to that of the UK and Poland: prohibiting any court from holding that national laws or practices regulating collective bargaining and collective action are inconsistent with the economic freedoms in the Treaties.

As to the content: An "anti-social dumping principle": exercise of economic freedoms without a guarantee of jobs and working conditions is an abuse which justifies collective action.

The social policy objective of "improved living and working conditions" (Article 136 EC) allows for a general principle of "non-regression" in EC law and extends to the freedom of Member States to require more favourable treatment of workers.

An interpretative framework for economic freedom to include the freedom of action of collective labour (trade unions) would include a rebuttable presumption in favour of collective action, and a criterion of "proportionality" based on the acquis communautaire social protecting workers. The exercise of economic freedoms derogating from fundamental rights is only permitted if justified as "proportionate".

The proposed Agency Workers Directive should guarantee equal treatment of crossborder agency workers.

\section{Strategies in the medium-term}

The "explanations" to the EU Charter should be "updated" to reflect a stronger social dimension. 
A standard social safeguard clause for directives could include protection of fundamental rights and collective agreements, and a clearer non-regression principle allowing more favourable provisions.

Transposition of the Services Directive may allow for challenges to the ECJ's interpretation of Article 49 in Laval by requiring service providers to respect fundamental rights to collective action, collective bargaining and collective agreements. Commission proposals should include a "social impact assessment".

The Lisbon Treaty's horizontal social clause, (new Article 5a EC) should be elaborated to make it effectively operational, given more precise meaning and adapted to specific Commission proposals. For example, to revise the Posting Directive to reverse the ECJ's interpretation in Laval.

\section{Strategies for the long-term}

The Treaty provisions on economic freedoms need to be re-drafted: to reduce their negative impact on fundamental rights of collective action and to protect workers; to prevent employers using economic freedoms against trade unions taking collective action (no horizontal direct effect), and the principle of subsidiarity should be reworked to reflect explicitly the protection of collective action.

Reform of the European Court of Justice includes establishment of a specialist tribunal: the chambre social, excluding competence to override fundamental rights (to collective action) protected in Member States, authorising the social partners to intervene in cases before the ECJ, and reconsidering the composition of the Court.

Reinforcing international labour law in the Treaties would mean ratification by the EU of the European Social Charter, explicit recognition of specific ILO Conventions as interpreted by the Freedom of Association Committee, and interpreting "proportionality" in light of international labour law.

\section{Introduction: The price of not remembering history is to repeat it}

A crucial element in maintaining a balance of economic power within EU Member States is the legal right of workers and their organisations to take collective action. A specific legal problem arises where national laws on collective action encounter EU law on free movement of goods, services, capital or workers. 
The decisions of the European Court of Justice (ECJ) in Viking, ${ }^{1}$ Laval ${ }^{2}$ and Rüffert $^{3}$ share a common premise: collective action which restricts the economic freedom of employers may violate EU law (on free movement, on posted workers and on public procurement). Although recognising the right to collective action as a fundamental right, the reasoning of the ECJ reflects doctrines long superseded in national legal discourse. Nineteenth century doctrinal ghosts of the dominance of market freedoms, long since revised to reflect the social model of industrial relations in twentieth century European welfare states, have returned to haunt EU labour law of the twenty-first century.

The decisions reveal a conflict between the ECJ's doctrine on collective action and the express policy choices of the EU legislature. In contrast to the decision in Viking, the EU legislature in Council Regulation (EC) No. 2679/98 of 7 December 1998 declared that free movement of goods was not to affect the right to strike. ${ }^{4}$ In the Services Directive, the EU legislature explicitly provided that fundamental rights to collective action, collective bargaining and collective agreements were not to be subject to EU law on free movement of services. ${ }^{5}$ In contrast to the decision in Laval, the EU legislature adopted the Posting Directive 96/71/EC in which Recital 22 states: “...this Directive is without prejudice to the law of the Member States concerning collective action to defend the interests of trades and professions". 6 In contrast to the ECJ decision in Rüffert, the EC directives on public procurement, revised in 2004, reflected the policy allowing

1 Case C-438/05, International Transport Workers' Federation, Finnish Seamen's Union v Viking Line ABP, OÜ Viking Line Eesti, decided 11 December 2007.

2 Case C-341/05, Laval un Partneri Ltd v Svenska Byggnadsarbetareförbundet, Svenska Byggnadsarbetareförbundet, avd. 1, Svenska Elektrikerförbundet, decided 18 December 2007.

3 Case C-346/06, Rechtsanwalt Dr. Dirk Rüffert v. Land Niedersachsen, decided 3 April 2008.

4 The "Monti" Regulation. Council Regulation (EC) No. 2679/98 of 7 December 1998 on the functioning of the internal market in relation to the free movement of goods among the Member States. OJ L337/8 of 12.12.98; Article 2: "This Regulation may not be interpreted as affecting in any way the exercise of fundamental rights as recognised in Member States, including the right or freedom to strike. These rights may also include the right or freedom to take other actions covered by the specific industrial relations systems in Member States".

5 Directive 2006/123/EC of the European Parliament and of the Council of 12 December 2006 on services in the internal market, OJ L376/26 of 27.12.2006. Article 1(7) provides: "This Directive does not affect the exercise of fundamental rights as recognised in the Member States and by Community law. Nor does it affect the right to negotiate, conclude and enforce collective agreements and to take industrial action in accordance with national law and practices which respect Community law". Recital 15 provides: "This Directive respects the exercise of fundamental rights applicable in the Member States and as recognised in the Charter of fundamental Rights of the European Union and the accompanying explanations, reconciling them with the fundamental freedoms laid down in Articles 43 and 49 of the Treaty. Those fundamental rights include the right to take industrial action in accordance with national law and practices which respect Community law".

6 Directive 96/71/EC concerning the posting of workers in the framework of the provision of services. OJ 1996, L18/1. 
public authorities to make compliance with collective agreements a contract performance condition, duly acknowledged by Advocate General Bot in his Opinion. ${ }^{7}$

Unless the ECJ's doctrines are rejected and the decisions reversed, the EU will pay the price of years of painful struggle to lay these doctrinal ghosts to rest. The price of not remembering history is to repeat it.

\section{The ECJ invents a new EU law on collective action}

\section{Uncertain criteria for the legality of collective action}

The European Court has spectacularly failed to establish clear rules of European labour law governing collective action. The Opinions of each of the Advocates General and each of the judgments of the ECJ in Viking and Laval prescribe very different principles for determining the legality of collective action. This does not produce certainty, nor inspire confidence in a judicial role in the regulation of collective action. The widely different propositions may be summarised very succinctly as follows.

For Advocate General Mengozzi in Laval, the lawfulness of primary collective action is subject to the criterion of "proportionality", which requires a real advantage which contributes significantly to workers' protection. The lawfulness of solidarity action depends on the lawfulness of primary action.

In complete contrast, for Advocate General Maduro in Viking, to be lawful, primary collective action must be taken before relocation. Solidarity action depends on whether it is voluntary.

The ECJ in Viking disregards Maduro's Opinion and, like Mengozzi, invokes the criterion of "proportionality". This requires a serious threat to jobs and conditions (not present where there is a legally binding guarantee of statutory provisions and collective agreements). But also, collective action must be suitable to achieve the objective, not go beyond what is necessary and any other less restrictive means have been exhausted. Solidarity action cannot be objectively justified, though it is to be balanced with workers' protection.

7 Paras. 58-60. The Preamble of Directive 2004/18/EC confirms that: "Contract performance conditions are compatible with this Directive provided that they are not directly or indirectly discriminatory and are indicated in the contract notice or in the contract documents (Recital 33). The Advocate General concluded that there was little doubt that a restriction on the freedom to provide service exists (para. 102). But the public authority was not violating Article 49 because it sought to ensure the protection of posted workers (para. 118). This was an appropriate means of preventing social dumping as it ensures that local workers and posted workers on the same site will be treated equally (para. 119). 
In contrast, the same ECJ in Laval looks to the Posting Directive for the criterion of lawful collective action. Collective action is lawful only to secure standards stipulated in the Posting Directive: legislation and collective agreements declared universally applicable in the construction sector. These are maximum standards. Transnational collective action to impose higher standards is unlawful as violating the Treaty's economic freedoms. Member States may extend this to include other collective agreements, other terms of employment and other sectors. But not negotiation at the workplace, which prevents transnational undertakings from ascertaining labour standards with certainty.

A superficially common criterion of "proportionality" masks real differences.

Advocate General Mengozzi in Laval explicitly invokes "proportionality", but this is not to be applied to primary collective action in support of pay claims, even if "excessive", though such action may be unlawful if linked to other terms of collective agreement. Similarly for solidarity action.

This is contradicted by the ECJ in Laval, for whom the criterion of "proportionality" is implicit: collective action is lawful only up to the maximum standards allowed by the Posting Directive. But not if standards are uncertain, as in negotiation at the workplace.

For Advocate General Maduro in Viking, the criterion of "proportionality" is, at best, implicit: primary action is lawful if before relocation; solidarity action is lawful if voluntary.

These concepts disappear in the ECJ's judgment in Viking, which evokes the criterion of "proportionality" explicitly. Primary action is lawful if suitable to meet a serious threat, is not more than necessary and less restrictive means available are exhausted. Solidarity action is not proportionate, though it may protect workers.

In sum, there are two broadly opposing principles in the judgments of Laval and $\mathrm{Vi}$ king, positing two different legal outcomes for the legality of collective action.

In Viking, legality depends on whether the action satisfies a general anti-social dumping principle (but subject to "proportionality").

In Laval, legality is subject to the maximum standards principle of the Posting Directive (which may be extended, but subject to "certainty").

So much for predictability... The outcome is deeply unsatisfactory.

\section{Horizontal direct effect against trade unions}

Trade unions are singled out by the Court as subject to complaints that their collective action violates the economic freedoms of others. The formulation is extremely wide: the economic freedoms may be invoked by "any individual who has an interest in compliance with the obligations laid down and... applies in particular to all agreements 
intended to regulate paid labour collectively". ${ }^{8}$ Moreover, the Court focuses such complaints on trade unions.

Doctrinal objections to horizontal direct effect include:

- collective agreements are not restrictions on freedom to provide services (as declared explicitly in the Services Directive);

- collective action is not a regulatory measure;

- trade unions are not regulatory bodies as "emanations of the State";

- horizontal direct effect violates freedom of association; and

- horizontal direct effect harmonises EC law on collective action.

Practical objections to horizontal direct effect include:

- a potential flood of complaints against collective agreements, and

- there are no practical criteria which distinguish agreements having regulatory effect.

\section{Unequal treatment of workers on grounds of nationality}

The fundamental principle of equal treatment regardless of nationality means that workers are entitled to the same terms and conditions regardless of nationality. The decision in Viking proposes restrictive criteria for lawful collective action against service providers aimed at ensuring the application to their employees in the host country of collective agreements equally applicable to workers in the host country. Laval and Rüffert go even further in restricting the kinds of collective agreements which may be applied only to agreements prescribing legally binding national minimum standards. The decisions of the ECJ challenge the principle of equal treatment of workers by distinguishing migrant workers from those employed temporarily by service providers.

\section{Violation of international labour law standards}

It is questionable whether the international labour law obligations of Member States are compatible with the constraints imposed by the ECJ on the right to collective action. These obligations are incumbent on them not only as signatories to a number of international law instruments (inter alia, ILO Conventions 87 and 98, the European Social Charter, Article 6(4)), but as a general principle of Community law.

8 Viking, para. 58. 


\section{Violation of the principle of subsidiarity}

The ECJ's decisions deal a potentially mortal blow to the national industrial relations systems of the EU Member States. The decisions restrict the right to collective action, restrict national collective bargaining systems and restrict labour standards to the minimum. Taken together, the decisions in Laval and Rüffert define a uniform model of industrial relations mandatory for all Member States. The ECJ's model of national industrial relations has the following characteristics as regards collective action, collective bargaining and collective agreements:

- national constitutional protection of the fundamental right of workers to take collective action is subordinate to economic freedoms of employers protected by the EC Treaty; the legality of collective action is subject to the criterion of "proportionality"; 9

- only legally binding collective agreements fixing national minimum standards can be enforced against employers (from other Member States and, probably, to avoid discrimination, also against domestic employers);

- flexible collective bargaining arrangements at local level are not enforceable against employers from other Member States as setting standards so uncertain as to constitute obstacles to free movement.

Few national systems currently conform to this model. Nobody can have expected the EU, let alone the ECJ, to arrogate to itself the competence to impose a uniform model of industrial relations radically altering systems developed over centuries in accordance with very different national histories, cultures and social partnership institutions. ${ }^{10}$

9 The criterion of "proportionality" is indeterminate. For example, according to the ECJ in Viking, it disaggregates into a number of indicators: (i) there must be a "serious threat" to jobs and working conditions; (ii) there is no legally binding undertaking by the employer to maintain existing collective agreements; (iii) the collective action must be suitable to achieve its ends; (iv) no other means less restrictive of economic freedoms is available; and (v) all alternative methods of achieving the union's objective have been exhausted.

10 Providing an overarching historical perspective, the ETUC stated in its letter attached to the ITF written submission in Viking: (paras. 4 and 6): "The precise contours of the rules governing collective action in each Member State are the outcome of different national historical experience... In the Member States of the EU the rules governing collective industrial action reflect an established equilibrium in the balance of forces between the social partners. It would produce a shock of incalculable magnitude if this equilibrium, carefully constructed over time in different Member States, were to be destabilised by an intervention reflecting Viking's interpretation of Community law". 


\section{A charter for "social dumping"}

Beyond this devastation wrought on national industrial relations systems, the ECJ in Viking also condemns transnational solidarity action which interferes with free movement of employers, despite acknowledging its objective to protect workers. ${ }^{11}$ It thereby established a legal framework for a balance of power which decidedly favours transnational employers against the protection of workers.

The proposed re-configuration of the legal framework of Member States' industrial relations systems by restricting collective action and collective agreements to limit labour standards to the minimum amount to a charter for "social dumping".

\section{In $\operatorname{sum} \ldots$}

The ECJ's doctrine on the EU law on collective action:

- subordinates collective action to the economic freedoms of employers,

- requires collective action to be justified by public policy,

- in accordance with a criterion of "proportionality" which requires, among other conditions,

- a "serious threat" to jobs and working conditions,

- suitability to achieve its ends,

- lack of other less restrictive means of action,

- exhaustion of all alternative methods, and

- is enforceable against trade unions through the doctrine of horizontal direct effect.

The Court's doctrine adopts the premise that fundamental social rights are to be interpreted narrowly where they restrict economic freedoms guaranteed by the Treaty. This doctrinal approach is fatal to the purpose and function of collective action of workers, which is precisely to restrict the economic freedom of employers. 12

The question is not whether the fundamental right to take collective action can be justified where it restricts employers' economic freedom. Rather, the Treaty's provi-

11 The ECJ condemns the ITF's Flags-of-Convenience (FOC) policy which: (para. 88) "results in shipowners being prevented from registering their vessels in a State other than that of which the beneficial owners of those vessels are nationals, the restrictions on freedom of establishment resulting from such action cannot be objectively justified". This is either a misunderstanding or a misrepresentation of the FOC policy which was previously clearly stated to concern negotiating rights and not registration (para. 8). This is offset by positive statement that immediately follows: "the objective of that policy is also to protect and improve seafarers' terms and conditions of employment".

12 As suggested above, it is questionable whether the international labour law obligations of Member States are compatible with the constraints imposed by the ECJ on the right to collective action. 
sions on economic freedoms should be interpreted to ensure respect for fundamental rights of workers, protected as a general principle of Community law.

The decisions threaten to overturn national industrial systems in Member States. The immediate victims are Finland, Sweden and Germany. But the same fate awaits others. The future of national industrial relations systems in the EU depends on whether these decisions and their consequences are reversed.

Aggressive employers have already sought to exploit the new EU legal doctrine to stop collective action protected by national laws. Early in 2008, the uncertain application of the criteria laid down by the ECJ to assess whether collective action which restricts economic freedom is lawful enabled British Airways to exploit this uncertainty to threaten legal action against Balpa, the pilots' trade union, which had voted by a large majority to take collective action. ${ }^{13}$

13 The Financial Times (12 March 2008, page 2) included the following report (Kevin Done), "BA uses EU law to prevent strike by pilots": "British Airways is looking to use competition law and a threat to seek 'unlimited damages' against the UK pilots' union in order to stop them going on strike. An overwhelming majority of BA's 3,200 pilots voted last month in favour of taking strike action over BA's plans to set up OpenSkies, a new airline subsidiary, with a pilot workforce separate to its mainline operations, which fly to and from Heathrow and Gatwick airports. Conciliation talks aimed at resolving the bitter dispute over future pilot staffing at BA subsidiary airlines in Europe collapsed on Friday. Balpa, the pilots' union, had planned to issue dates for its first strikes, which would ground the airline, but was forced to postpone the move when BA warned the union it had 'a valid legal claim' against it, if it 'took the disproportionate step of calling a strike'. The union said yesterday that BA was claiming its pilots could not legally pursue their concerns over job security because of European legislation. Balpa said BA was claiming it had a fundamental right under article 43 of the EC Treaty to establish operations in another European Union member state. The right included both establishing new airline services in other EU states, as well as acquiring existing operations from other airlines. BA was claiming that Balpa was seeking to limit that right by insisting that there should be a single pilot workforce with a shared seniority list to determine pilot employment. BA has already begun to recruit pilots for OpenSkies. Jim McAuslan, Balpa general-secretary, said BA 'should be at the negotiating table' and not using European legislation, designed to ensure free competition between companies, in order to restrict the freedoms of trades unions in industrial disputes. He said that Balpa was seeking a High Court hearing to clarify whether the European legislation could be used in an industrial dispute and whether the union could rely on the strike ballot to avoid a claim for unlimited damages. The union has won court backing for the strike vote to remain valid beyond the normal 28-day limit until applicability of European law is clarified. It rules out taking any strike action during the Easter holiday period. BA said yesterday it was 'pleased' Balpa had recognised it had 'a strong legal case'. It said that 'any strike action would be unlawful', and the union had therefore decided not to issue strike dates. OpenSkies is BA's most ambitious attempt to take advantage of the US/European Union 'open skies' treaty liberalising transatlantic aviation". On 15 March 2008, more than 1,000 British Airways pilots marched on BA's Heathrow headquarters over plans to use non-BA pilots in a new subsidiary after pilots had voted for industrial action, but BA applied for a legal injunction to prevent it going ahead. A spokesman said given that roughly 2,000 of BA's 3,000 pilots are usually either on duty or resting before or after flights, the turnout was very high. "Every pilot who could be there was there, which was quite remarkable," the spokesman said. 
The potential cost of defending against such legal threats forced Balpa to withdraw from collective action. ${ }^{14}$ The lesson is clear. The uncertain application of the criteria laid down by the ECJ to assess whether collective action which restricts economic freedom is lawful enables employers (here British Airways) to exploit this uncertainty to threaten and thereby possibly obtain an interim injunction. ${ }^{15}$ The cost and delay entailed in defending against such legal threats effectively deters collective action. In prac-

14 The union's legal action was heard by the High Court in London over four days, from 19-22 May 2008. The outcome was immediately reported in the on-line edition of the Financial Times of 22 May 2008: "British Airways' new transatlantic airline has been cleared for take-off after the carrier's pilots on Thursday unexpectedly abandoned a High Court review of their right to strike. BA's launch of OpenSkies - an upmarket carrier that will fly between Europe and the US - had been marred by the threat of a crippling work stoppage at its mainline operations during the peak summer travel season. Members of the British Air Line Pilots Association overwhelmingly voted to strike over the initiative in February, claiming that it could be used as a 'Trojan horse' to usher less favourable working conditions across the airline. The union's decision to withdraw its challenge over the legality of industrial action means that OpenSkies remains on track to operate its first flight from Paris to New York on June 19. Balpa has agreed not to reballot its members to authorise a strike. The volte face came on the fourth day of a judicial review hearing over whether a walkout by pilots were to violate Article 43 of the Treaty of Rome, which gives any European Union-based company the right to set up a business in other EU states. John Hendy QC, for Balpa, on Thursday told the High Court the union simply could not afford to pursue the case through an exhaustive series of appeals. "It is very clear that win, lose or draw this case, there will be further litigation by way of appeals and further appeals, the House of Lords and perhaps the European Court of Justice as well, which will have the effect of increasing exposure to costs of whichever party ultimately loses", he said. "It would plainly be madness to embark on industrial action with the risk that, in the end, it would be declared unlawful". The first tickets for OpenSkies flights between Paris Orly airport and New York's JFK went on sale on Thursday. BA said it 'welcomed' Balpa's decision to withdraw the proceedings, reaffirming its stance that the new carrier posed no threat to the jobs, pay or working conditions of its mainline pilots. Balpa said it now planned to embark on an EU-wide campaign to clarify the purpose of Article 43, to ensure it could not be used to undermine workers' right to strike. The High Court tussle was being closely watched by unions throughout Europe, who feared that a ruling against Balpa would give multinationals another weapon to block industrial action. "We shall be pressing for a review of this law which has prevented British trade union members from protecting their careers", said Jim McAuslan, Balpa general secretary. BA set up the OpenSkies subsidiary to take advantage of the liberalisation of transatlantic aviation agreed last year by the US and the EU. The carrier's Paris-New York flights this June will be the first occasion when BA has operated long-haul services that do not begin or end in the UK".

15 The option of Balpa seeking to refer the legal issues to the ECJ was not pursued. Questions could include, e.g.: (i) Does compliance with domestic law on collective industrial action constitute a criterion for national courts assessing whether the fundamental right to take collective action restricts the economic freedom of employers in accordance with EC law? (ii) What further criteria does EC law provide to enable judges to determine whether the fundamental right to take collective action restricts the economic freedom of employers in accordance with EC law? (iii) What, if any, are the circumstances in which domestic courts may issue injunctions restraining the exercise of the fundamental right to take collective action which allegedly restricts the economic freedom of employers in accordance with EC law? (iv) Is it consistent with EC law for a domestic court to provide an interim remedy on the basis of the "proportionality" of collective action in changing circumstances and future and unforeseeable events? 
tice, the exercise of the fundamental right to strike, ostensibly protected as a general principle of EU law, is denied.

\section{$I V$. Scope of action at European level after the Lisbon Treaty}

This new EU law on collective action was not envisaged when the Lisbon Treaty was proposed. In the aftermath of the rejection of the Lisbon Treaty in the Irish referendum of 12 June 2008, the main objective of this paper is to explore the scope for action at European level, looking to short, medium and long-term strategies.

\section{$V$. Strategies in the short-term}

Apart from giving legally binding effect to the EU Charter of Fundamental Rights, the Lisbon Treaty did not contribute greatly to the social dimension of the EU. And, of course, the new EU law on collective action was not foreseen. Some Member States would have preferred a stronger social dimension. It is possible to reverse some of the negative consequences of the ECJ's decisions and to enable those Member States to undertake a commitment to a stronger social dimension. ${ }^{16}$

Two issues arise:

- what would be the legal form of such a commitment;

- what would be the substantive content of such a commitment?

\section{Legal form}

A number of alternatives may be envisaged.

16 The following draws on some of the ideas prepared for the ETUC Congress in Seville in May 2007 by a group of European labour law professors, the Research Group on Transnational Trade Union Rights of the ETUI-REHS. B. Bercusson (ed) Manifesto for a Social Constitution: 8 options for the European Union, European Trade Union Institute (ETUI-REHS), Brussels, 2007, (133 pp.) also available in French and German. 


\section{A Protocol 17}

A number of Member States could adopt a Protocol (attached to the Lisbon Treaty) on a stronger social dimension. These Member States would undertake to persuade all Member States to agree to attach this Protocol to the Treaties, though it would only bind those Member States which adopted it.

\section{Enhanced cooperation 18}

Article 43 TEU allows for enhanced cooperation by a majority of the Member States. If at least 14 Member States agreed that, alongside the Lisbon Treaty, they wished to adopt provisions for a stronger social dimension, the mechanism of enhanced cooperation could allow this, leaving it open to other Member States to join later.

\section{The "Schengen" model19}

A stronger social dimension could follow the road of the Schengen model. The Schengen Agreement harmonising border controls was made initially by only 5 Member States in 1985. More Member States gradually joined, so that it now includes $25 \mathrm{Mem}-$ ber States (except Ireland and the UK, but including also Iceland, Norway and Switzerland). In 1997, a Protocol attached to the Treaty of Amsterdam incorporated these advances into the legal framework of the EU. A "Social Schengen Agreement" could be adopted alongside the Lisbon Treaty.

\section{A non-binding Social Declaration 20}

Member States desiring a stronger social dimension could attach to their ratification of the Lisbon Treaty a commonly agreed "social declaration". Though not legally binding, this could have a future impact on the political agenda of the EU institutions, including the Commission's action programme and the Court's interpretation of the EU Charter's social provisions.

17 See B. Bercusson, “Option 2: A 'Social Protocol' to the Constitutional Treaty", ibid., pp.30-31 and 63-73.

18 See Antoine Jacobs, "Option 3: Enhanced cooperation", ibid., pp.32-33 and 75-63.

19 See Isabelle Schömann, "Option 4: The Schengen Model: "Variable Geometry", ibid., pp.33-34 and 85-94.

20 See Yota Kravaritou, “Option 6: A Non-Binding Social Declaration”, ibid., pp.36-37and 105-110. 


\section{An interpretative instrument (inverse "opt-out") 21}

The UK and Poland attached an "opt-out" to the Lisbon Treaty excluding application of the EU Charter to their laws. An inverse "social opt-out" could be modelled on Article 1 of this opt-out: "The Treaties do not extend the ability of the Court of Justice or any court or tribunal to find that the laws or practices of the Member States regulating collective bargaining and collective action are inconsistent with the economic freedoms that they affirm". 22 Member States desiring a stronger social dimension could attach this formula to their ratification of the Lisbon Treaty as an interpretative guide.

\section{Content ${ }^{23}$}

The Lisbon Treaty proposes to replace the present Article 2 of the Treaty on European Union with a new Article 2, including references to "social progress" and "social justice". 24 The new Article 2 affirms that "The Union shall establish an internal market". ${ }^{25}$ But the internal market is only a means towards achieving a "social market economy, aiming at full employment and social progress" and the Union "shall promote social justice and protection". 26

It may be necessary to redress the imbalance in Community law, as presently interpreted by the ECJ (and also the present Commission), by challenging the primacy given to the internal market over all other Community policies.

In Laval and Viking, the ECJ regarded collective action primarily in terms of its impact on the economic freedoms of the common market. ${ }^{27}$ What was shocking, if not

21 See B. Bercusson, “Option 7: An Interpretative Instrument”, ibid., pp.37-38 and 111-123.

22 Cf. Council Regulation (EC) No. 2679/98 of 7 December 1998 on the functioning of the internal market in relation to the free movement of goods among the Member States. OJ L337/8 of 12.12.98; Article 2, quoted above.

23 What follows are only a few illustrative suggestions among many possibilities.

24 Replacement Article 2(3) TEU. "The Union shall establish an internal market. It shall work for the sustainable development of Europe based on balanced economic growth and price stability, a highly competitive social market economy, aiming at full employment and social progress, and a high level of protection and improvement of the quality of the environment. It shall promote scientific and technological advance. It shall combat social exclusion and discrimination, and shall promote social justice and protection, equality between women and men, solidarity between generations and protection of the rights of the child". (italics added) Formerly in the Constitutional Treaty, Part I, Article I-3(3).

25 Ibid.

26 Ibid.

27 Sophie Robin-Olivier, "Son raisonnement est, dans les grandes lignes, empreint du plus grand classicisme". "Liberté de l'action syndicale vs liberté d'établissement", Revue de Droit du Travail, Janvier 2008, p. 8. 
surprising, is how little weight was given by the ECJ to other, arguably equal if not more prominent, EU policies. These include fundamental rights (the EU Charter's freedom of association, collective bargaining and collective action), improvement of working conditions (Article $136 \mathrm{EC}$ ), the public policy of protection of workers against unfair competition (social dumping), and so on. Each of these was mentioned in the judgments in Laval and Viking, but ultimately subordinated to the economic freedoms of employers in the common market.

This is a threat to the entire acquis communautaire social. If economic freedoms override collective action, they could be invoked to circumscribe the rest of the acquis communautaire social. ${ }^{28}$ The following are only a few proposals which could be reflected in one of the legal forms suggested above to accompany ratification of the Lisbon Treaty.

\section{An "anti-social dumping principle" against abuse of the exercise of economic freedoms}

Laval and Viking both contain expressions of concern by the Advocates General and the ECJ about "social dumping". The unrestrained exercise of economic freedom of movement may threaten existing jobs and working conditions. This may be characterised as an "abuse" of the exercise of economic freedoms. A condition of the exercise of economic freedom is that there is a guarantee of existing jobs and working conditions. Failure to provide such a guarantee justifies collective action against such an abuse.

28 For example, economic freedoms may be invoked against the many directives requiring information and consultation of workers and their representatives. Such requirements restrict the economic freedom of management to make speedy decisions in re-structuring undertakings. An item in the Financial Times of 28 February 2008 (page 24) reported: "A new power struggle has broken out between Gaz de France and Suez, this time between the two companies' European works councils, which are crucial to breaking the union impasse that has repeatedly delayed the creation of the $\mathrm{E} 75 \mathrm{bn}$ (\$113bn) energy giant. GdF's European unions are demanding that they represent the enlarged group when the merger is complete before they will give the non-binding opinion that is required under French law before the companies' board can approve the deal. Suez is resisting the demand and both sides are seeking agreement ahead of the next works council meeting on March 11. Failure to find a compromise could throw the merger timetable off track, further delaying a deal that has already been two years in the making. GdF's French unions also have yet to give their opinion and have been using efficient delaying tactics against the merger. Jean-Francois Cirelli, GdF chief executive, said he remained 'reasonably confident' that the deadline of June 30 could still be met, and that the European unions would give their opinion at the March meeting, Discussions with unions had entered a more positive phase, he said". 


\section{A non-regression clause}

The references in the social policy objectives listed in Article $136 \mathrm{EC}$ to "improved living and working conditions" and "harmonisation while the improvement is being maintained" argue for a general principle of "non-regression" in Community social policy. This could be made more explicit and elaborate as a principle of Community law. ${ }^{29}$

\section{A more favourable treatment clause}

The ECJ adopted a bizarre interpretation in Laval of Article 3(7) of the Posting Directive to restrict the freedom of Member States to require more favourable treatment of workers. This was in order to support its view of the Directive as a stipulating a "maximum standard". ${ }^{30}$ This could be addressed by amending the Posting Directive. But this

29 The proposed revision of the Working Time Directive exemplifies the need for such a principle. Amended proposal for a Directive of the European Parliament and of the Council amending Directive 2003/88/EC concerning certain aspects of the organisation of working time - Political agreement on a common position. SOC 357, CODEC 758, Brussels, 11 June 2008.

30 Article 3(7) of the Posting Directive 96/71/EC appeared to support this principle: "Paragraphs 1 to 6 shall not prevent the application of terms and conditions of employment which are more favourable to workers". The ECJ interpreted this provision as follows (paras. 79-80; italics added): "It is true that Article 3(7) of Directive 96/71 provides that 'paragraphs 1 to 6 are not to prevent the application of terms and conditions of employment which are more favourable to workers'. In addition, according to recital 17 , the mandatory rules for minimum protection in force in the host country must not prevent the application of such terms and conditions. Nevertheless, Article 3(7) of Directive 96/71 cannot be interpreted as allowing the host Member State to make the provision of services in its territory conditional on the observance of terms and conditions of employment which go beyond the mandatory rules for minimum protection. As regards the matters referred to in Article 3(1), first paragraph, (a) to (g), Directive 96/71 expressly lays down the degree of protection for workers of undertakings established in other Member States who are posted to the territory of the host Member State which the latter State is entitled to require those undertakings to observe. Moreover, such an interpretation would amount to depriving the directive of its effectiveness". Reiterated in Rüffert, paras. 32-33. Contrast the Opinion of Advocate General Bot in Rüffert: (paras. 81-83, italics added) "In addition, I would remind the Court that the $17^{\text {th }}$ recital in the preamble to that Directive provides that 'the mandatory rules for minimum protection in the host country must not prevent the application of terms and conditions of employment which are more favourable to the workers'. The first subparagraph of Article 3(7) of the directive translates this intention of the Community legislature by stating that '[p]aragraphs 1 to 6 shall not prevent the application of terms and conditions of employment which are more favourable to workers". In my view, there are two aspects to this last provision. First, it means that the mandatory nature of the protective rules in force in the Member State where the services are performed may be eclipsed by application of the rules in force in the State in which the provider is established if those rules provide for terms and conditions of employment that are more favourable to the posted workers. Secondly, and it is this aspect which is relevant in the present case, Article 3(7) of Directive 96/71 also, in my view, permits the Member State where the services are performed to improve, for the matters referred to in Article 3(1) of the 
principle is found in many other legislative provisions and the ECJ's interpretation may be dangerous more generally. An attempt could be made to clarify and extend the principle.

\section{An interpretative framework for economic freedoms}

The market economy is not limited to the economic freedoms of enterprises only. Market freedom includes the freedom of action of collective actors both of capital (enterprises) and labour (trade unions). ${ }^{31}$ The economic freedom of movement of one side should not be invoked to restrain the economic freedom of action of the other side, as the ECJ has done in Viking and Laval. ${ }^{32}$ This should be remedied by amendments providing a more even-handed interpretative framework for economic freedoms. For example:

\section{a) A rebuttable presumption in favour of collective action}

A rebuttable presumption that collective action is presumed to be in response to a serious threat to jobs and working conditions. This may be rebutted when challenged by the employer. ${ }^{33}$

directive, the level of social protection which it wishes to guarantee to workers employed in its territory and which it can therefore apply to workers posted there. Hence in principle, this provision authorises the implementation of enhanced national protection". See also paragraphs 90-98 of the Opinion.

31 As stated by Miguel Poiares Maduro: “...the system requires a set of social rights that can be said to guarantee participation and representation in market decisions and, by internalizing costs which tend to be ignored in those decisions, increase efficiency... rights of participation and representation such as the freedom of association, the right to collective bargaining, and the right to collective action should be considered as instrumental to a fully functioning integrated market which can increase efficiency and wealth maximization". "Striking the Elusive Balance Between Economic Freedom and Social Rights in the EU", in P. Alston (ed), The EU and Human Rights (Oxford University Press, 1999), pp. 449-472, at 470.

32 In a parallel case of alleged conflict between the Treaty's provisions on competition and collective agreements, the ECJ had refused to outlaw collective agreements in order to preserve competition. Albany International BV v. Stichting Bedrijfspensioenfonds Textielindustrie, Case C-67/96; with Joined cases C-115/97, C-116/97 and C-117/97; [1999] ECR I-5751. Unfortunately, the ECJ rejected this approach in Laval and Viking, distinguishing the Treaty's competition provisions from free movement provisions.

33 As stated in Viking, the presumption may be rebutted if the employer gives a legally binding undertaking providing guarantees in the form of a collective agreement. In the absence of such a collective agreement, judges should not intervene to restrain collective action in the course of collective bargaining. As stated by Advocate General Mengozzi in his Opinion in Laval. 


\section{b) Interpreting "proportionality" in light of the acquis communautaire social}

The lawfulness of collective action is conditional on "proportionality" (Viking) and is explicitly linked to the Posting Directive (Laval). Why the Posting Directive? Collective action is proportionate where the employer fails to comply with obligations under the general acquis communautaire social protecting the rights of workers as an objective of general interest recognised by the Union. ${ }^{34}$

c) Human rights are not mere derogations from economic freedoms; rather the reverse

The ECJ regards the fundamental right to collective action as a derogation from the Treaty's guarantee of economic freedoms. As such, collective action must be justified. ${ }^{35}$ The ECJ also declares the fundamental right to collective action to be protected as a general principle of Community law. The Lisbon Treaty provides that the EU Charter is to have the same legal status as the Treaties and proposes that the EU ratifies the European Convention on Human Rights. The ECJ's approach should be reversed: economic freedoms may exceptionally derogate from fundamental rights guaranteed by Community law, but this has to be justified, and any derogation from fundamental rights is only permitted if "proportionate" (necessary and no alternative available). ${ }^{36}$

\section{The Agency Workers Directive: Equal treatment of agency workers includes cross-border workers}

The decisions in Laval and Viking threaten the principle of equal treatment of crossborder workers. The Commission's proposal on Temporary Agency Workers included a requirement that agency workers be treated equally to comparable workers employed by

34 In doctrinal terms, this is a specifically EU criterion based on the acquis communautaire social reflected in Articles 27 and 28 of the EU Charter: protection by EU law of the transnational economic freedom of employers is balanced with protection of transnational collective action by workers who should be properly informed and consulted before decisions affecting them are made. The common element is the prevention of "social dumping".

35 This approach, also applied by the ECJ to freedom of assembly and association in Schmidberger (Case C-112/00, Eugen Schmidberger, Internationale Transporte und Planzuge v. Republic of Austria, [2003] ECR I-5659, 12 June 2003) and to human dignity in Omega (Case C-36/02, Omega Spielhallen- und Automatenaufstellungs-GmbH v. Oberburgermeisterin der Bundesstadt Bonn, [2004] ECR I-9609, 14 October 2004) is offensive to fundamental human rights.

36 This is the approach proposed by Advocate General Stix-Hackl in her Opinion in Omega. 
the user employer. ${ }^{37}$ This could apply to temporary agencies who post workers to other Member States. ${ }^{38}$ The principle of equal treatment could be applied to posted workers generally. For example, where posted by employers to work alongside comparable workers employed by other employers, or in sectors regulated by collective agreements covering comparable workers.

\section{Strategies in the medium-term ${ }^{39}$}

The viability of strategies in the medium-term depends on the political context; not least, the elections to the European Parliament and of a new Commission in 2009.

The following proposals aiming for a stronger social dimension may involve new or revised directives, but may have wider institutional implications.

\section{1. "Update" the "explanations" to the EU Charter}

These "explanations" were "updated" by the Convention on the Future of Europe and again by the Member States at the summit of June 2004. In particular, the explanations accompanying Article 28 on collective action were "updated" at the initiative of the UK government in an attempt to reduce its scope and impact. These "explanations" could be revisited, not least since the UK has opted out of the Charter. They could be revised to reflect a more satisfactory equilibrium between the fundamental right "to take collective action" and economic freedoms. 40

37 Commission of the European Communities, Proposal for a Directive of the European Parliament and the Council on working conditions for temporary workers, COM(2002) 149 final, Brussels, 20 March 2002; Amended Proposal, COM(2002) 701 final, Brussels, 28 November 2002. See now the Amended proposal for a Directive of the European Parliament and the Council on working conditions for temporary workers - Political agreement on a common position, Brussels, 11 June 2008. SOC 358, CODEC 761.

38 For a discussion of transnational temporary agency work (excluded from the Services Directive) and the need for a directive, see B. Bercusson and N. Bruun, "Free movement of services, transnational temporary agency work and the acquis communautaire", in K. Ahlberg, B. Bercusson, N. Bruun, H. Kountouros, C. Vigneau, L. Zappalà, Transnational Labour Regulation: A Case Study of Temporary Agency Work, Peter Lang, Brussels, 2008.

39 Of course, some of the proposed short-term strategies become medium-term if they do not succeed in the short-term, and so on...

40 Revision of the "explanations" to Article 28's "right to negotiate and conclude collective agreements at the appropriate levels" might also assist the social dialogue, not least at EU level. There is no need to limit this to Article 28. The ECJ's reasoning in Schmidberger might attract support from human rights lobbies for a revision of the "explanations" to Article 12: Freedom of assembly and of 


\section{A standard social safeguard clause in directives}

Directives already contain standard clauses; for example, regarding obligations of Member States as regards effective enforcement. A standard social safeguard clause could be formulated for inclusion in directives. ${ }^{41}$ This could include the following provisions:

- explicitly protecting national standards (e.g. as in the "Monti" Regulation);

- substantive provisions protecting fundamental rights and collective agreements per se (as in the Services Directive);

- a non-regression principle, following Article 136 EC, made more explicit and elaborate; or

- allowing national provisions more favourable to workers; 42

- specifying obligations on Member States to provide information to employers on labour standards. ${ }^{43}$

\section{Monitoring transposition of the Services Directive}

Laval, by asserting the power of Article $49 \mathrm{EC}$, implicitly challenges the attempt in the Services Directive to protect fundamental rights to collective action and collective bargaining and collective agreements from liberalisation of services. ${ }^{44}$ Member States transposing the Services Directive may offer an opportunity to promote legislation challenging the ECJ's interpretation of Article 49. This may allow for litigation enabling the ECJ to reconsider its decision in Laval.

\section{Social impact assessments}

Commission proposals should include a "social impact assessment". The content should assess the proposal not only in terms of specific social benchmarks, such as minimum standards required, but in terms of its potential impact on industrial relations

association. Similarly, Article 27: Workers' right to information and consultation within the undertaking could also be revisited.

41 The proposed Lisbon Treaty includes a horizontal social clause, Article 5A.

42 Overriding the ECJ's bizarre interpretation of Article 3(7) of the Posting Directive.

43 A requirement in the public procurement directives, said to promote the transparency of the single market.

44 E.g. in Articles 1(7)), 4(7) 16(3), Recital 15... 
systems and, in particular, collective bargaining and collective agreements. The formulation of this assessment could engage the social partners. 45

\section{Operationalising the Lisbon Treaty's horizontal social clause}

The Lisbon Treaty's horizontal social clause, Article 5A, provides:

"In defining and implementing its policies and activities, the Union shall take into account requirements linked to the promotion of a high level of employment, the guarantee of adequate social protection, the fight against social exclusion, and a high level of education, training and protection of human health".

This could be elaborated so as to make it more effectively operational. Its terms could acquire more precise meaning and adapted to specific Commission proposals. Examples follow.

\section{Revise the Posting Directive}

The ECJ's interpretation of the Posting Directive in Laval is unorthodox, if not wrong as contradicting the aim of the EU legislator. The EU legislator could amend the Posting Directive in a number of ways; e.g.:

- extending the scope of collective agreements establishing standards binding foreign enterprises which post workers, and making mandatory what are currently only options under Article 3(8) of the Directive (amending the definitions of applicable collective agreements determining conditions applicable to foreign service providers); 46

- make clear that both legislative sanctions and collective action are available to enforce these standards;

- expanding the scope of "public policy" provisions which may be extended to apply to foreign services providers under Article 3(10) of the Directive; 47

- making clear the power of Member States to require more favourable conditions, reversing the ECJ's bizarre interpretation of Article 3(7) of the Directive;

45 Indeed, it might be a subject for social dialogue. This extends the Interinstitutional Agreement on Better Lawmaking of December 2003 between the Commission, Council and Parliament to include the social partners, recognising their privileged position. The "opinion" foreseen in Article 138(3) EC could include a social impact assessment

46 This could introduce criteria of decentralisation and flexibility to provide for articulation between national/sectoral and local/enterprise/workplace agreements. This could accommodate the flexible qualities of the Nordic systems advocated by the Commission.

47 Not least in anticipation of the pending decision in Case C-319/06, Commission v. Luxembourg, Opinion of Advocate-General Trstenjak, 13 September 2007. 
- making the equal treatment principle applicable to migrant workers applicable to posted workers; if necessary, by declaring that posted workers are to be treated equally to domestic workers after working for a specified (short) period in the host Member State.

By legitimizing collective agreements specifically applicable to transnational movement of labour, this would reinforce the principle of non-discrimination/equal treatment of workers, collective bargaining systems which are decentralised but articulated, legislative mechanisms available to enforce these standards and the right to collective action to support these standards.

\section{Strategies for the long-term}

The ECJ in Viking and Laval relied on the EC Treaty's provisions guaranteeing economic freedoms. These were characterised as equivalent, and indeed potentially superior to fundamental rights. ${ }^{48}$ Action at European level is required for a stronger social dimension in the long-term by revising the Treaties.

The attack could be on the substance of the ECJ's approach to EC law (market primacy), or on the exercise by the EU of its competences (subsidiarity), and hence the scope of the ECJ's jurisdiction; or indeed both. ${ }^{49}$ Three specific proposals may be suggested.

\section{Revise Treaty provisions on economic freedoms}

The task is to re-draft the provisions on economic freedoms in such a way as to reduce or eliminate their negative impact on fundamental rights; specifically, on collective action, and so as to protect workers.

For example, the primacy of economic freedoms could be attacked by reformulating the provisions to include the statement that economic freedoms may not be interpreted

48 Unfortunately, at present, the formal supremacy of EU law is often translated into, and reinforces, the substantive primacy of promoting economic freedoms in the common market.

49 Or a combination, focussing on the limitation to transnational matters? The ECJ may determine rules on transnational collective action, but not on matters purely internal to Member States not affected by EC law. What is the consequence if there are radically different rules on transnational and national collective action, and between the national rules in different Member States? Do such differences inherently impede free movement, deterring employers, and hence violate the Treaty? Such differences might impede free movement of workers, as some might avoid moving to Member States where their rights to take collective action are more restricted. What are the criteria of "transnationality"? Is national action caught only if there is actual obstruction of a transnational market relationship, or is it sufficient if it merely (potentially) impedes market access? 
as affecting in any way the exercise of fundamental rights based on the "common constitutional traditions" of the Member States; specifically, as regards protection of the right to collective action. ${ }^{50}$ This also removes the primary obligation of Member States (and national law) to comply with the EU internal market objective. ${ }^{51}$

The fundamental economic freedoms of employers are usually exercised through the collective organisational form of corporate capital. The Treaty's economic freedom of workers applies only to individual workers. Another approach would be to draft a fifth fundamental economic freedom of collective organisations of workers. ${ }^{52}$ This would promote an interpretation of the Treaty recognising that collective action by workers is consistent with the effective functioning of the internal market. Workers and trade unions, as market participants, may take collective action to ensure their voice is heard and their interests are taken into account, a feature essential to the effective functioning of the internal market. Collective bargaining, collective agreements and collective action are essential to the effective and equitable functioning of the labour market. This balances the discrepancy between the power of employers benefiting from European transnational economic integration, and the relative weakness of a labour movement largely confined to national boundaries in its collective bargaining and collective action.

Finally, as proposed under short-term measures, the Treaties could explicitly provide for an "anti-social dumping principle" against abuse of the exercise of economic freedoms.

\section{Revise the Treaty to prevent employers using economic freedoms against trade unions taking collective action (horizontal direct effect)}

EC Treaty Articles 43 (freedom of establishment) and 49 (freedom of services) were aimed at regulatory action by public authorities (vertical direct effect) or professional associations regulating access to the labour market. This is not the case with trade unions engaging in collective action in pursuance of a collective agreement which regulates substantive terms and conditions of employment, not free movement.

To apply horizontal direct effect to collective agreements means the ECJ will be flooded with endless references from national courts asking whether a specific collective agreement in a particular Member State's collective bargaining system possessed the requisite regulatory effect.

50 As in the "Monti" Regulation, Council Regulation (EC) No. 2679/98 of 7 December 1998 on the functioning of the internal market in relation to the free movement of goods among the Member States. OJ L337/8 of 12.12.98; Article 2, quoted above.

51 Thus reinforcing the ECJ's jurisprudence establishing a general principle of substance that EC law protects fundamental rights.

52 This could build on the precedent of the recognition of management and labour as institutional actors in the Maastricht Agreement's provisions on social dialogue. 
The Treaty should be revised to clarify that economic freedoms may not be invoked against trade unions taking collective action.

\section{Revise the subsidiarity principle to exclude EC competence to regulate collective} action

National laws on collective action by workers and trade unions reflect an equilibrium carefully constructed over time. It is an area of law jealously guarded by Member States. The principle of subsidiarity aims to preclude EC law intervening as EU intervention could be destabilising. Transnational collective action raises difficult questions in private international law: which national court has jurisdiction and the law of which Member State applies. Different laws and different courts take different views regarding the legality of cross-border collective action.

The Services Directive rejected the "country of origin" principle to protect national social models, in particular, as regards collective bargaining, collective agreements and collective action: "the exercise of fundamental rights as recognised in the Member States and Community law... the right to negotiate, conclude and enforce collective agreements and to take industrial action in accordance with national law and practices..." (Article 1(7)). The principle of subsidiarity could be reworked to reflect explicitly the protection of collective action.

\section{Reform the European Court of Justice}

\section{a) Structure of the ECJ}

There have been reforms to the structure of the ECJ in the past. ${ }^{53}$ The decisions in Viking, and particularly in Laval with its bizarre interpretation of the Posting Directive and dramatic consequences for the entire Swedish system of industrial relations, make a powerful case for establishment of a specialist tribunal: the chambre social of the European Court.

\section{b) Competences of the ECJ}

The ECJ (and the EU) should not have competence to override fundamental rights (to collective action) protected in Member States. ${ }^{54}$ This could be reinforced, for example,

53 The Single European Act 1986 created the European Court of First Instance. The Treaty of Nice 2000 allows for the creation of specialist tribunals; the first is the European Civil Service Tribunal.

54 As in the "Monti" Regulation, quoted above. 
specifically as regards collective action, by curtailing the jurisdiction of the ECJ. 55 Article 234 EC could be amended to limit the discretion of national courts to make preliminary references to the ECJ on matters concerned with collective action. 56

\section{c) Procedures of the ECJ}

The ETUC's experience in Viking demonstrated that, although cases before the ECJ may be of vital concern to trade unions, the rules of procedure before the Court make it difficult for trade unions to make representations. The consequence is that the ECJ may not be alerted to important issues. In particular, the rules of procedure should acknowledge that the privileged status of the social partners as institutional actors in the EU Treaty authorises them, like the Member States, to intervene before the ECJ. 57

\section{d) Composition of the ECJ}

The legislative institutions of the EU, Council and Parliament (and in the future, even the Commission) reflect the relative weight of different Member States. The European Court does not: each Member State appoints one judge. The latest enlargement means there are 15 judges from the "old" Member States and 12 from the "new" Member States. 58

55 This was the effect of the decision in Albany, where the ECJ ruled that collective agreements fell outside the competition provisions of the Treaty.

56 In European Social Policy: Between fragmentation and integration, (eds. Stephan Liebfried and Paul Pierson, The Brookings Institution, Washington, 1995), the editors offer insights into the role of the courts in EC labour law: (p. 26) "...joint-decision traps in the United States helped push national initiatives for social reform in a rights-based, court-led direction, with disappointing results... the relatively activist role of the European Court of Justice in social policy stems in part from a similar desire of European federalists to avoid the daunting problems associated with joint decisionmaking through the European Council". And pp. 36-37: "...the dilemmas of shared decision-making in the EU lead to strategies of circumvention... the efforts of actors to escape the gridlock in social policy-making is a central theme. For advocates of social integration, institutional constraints within the Union have made court-led policy development an important path of social reform... [However] multi-tiered systems make centralized policymaking difficult for a reason - to protect local interests - and circumvention of these protections is likely to generate resentment... one aspect of the current disquiet over the Union's 'democratic deficit'...".

57 This should be extended to allowing the social partners to take legal action against the Member States or the other EU institutions for failing to observe Community law (e.g. against the Commission for failure to observe Treaty provisions on the social dialogue process).

58 The Viking and Laval cases were illustrations of the fact that the disparity in labour costs among "new" and "old" Member States and the willingness of enterprises to exploit economic freedoms has the potential of social dumping as between "old" and "new" Member States. There was a clear difference between the submissions to the ECJ of the "old" (except for the UK) and "new" Member States. See B. Bercusson, "The Trade Union Movement and the European Union: Judgment Day", (2007) 13 European Law Journal (No. 3, May), pp. 279-308. The Court deciding Laval and Viking 


\section{Reinforce international labour law in the Treaties}

\section{a) The European Social Charter}

The Lisbon Treaty proposes that the EU ratifies the European Convention on Human Rights. Article 136 EC already refers to the Community "having in mind" the European Social Charter (ESC) of 1961. The Treaty should allow for ratification by the EU of the ESC, which includes the right to strike in Article 6(4).

\section{b) ILO Conventions}

All Member States, as members are bound by the ILO Declaration of Principles of 1998, and have ratified ILO Conventions 87 and 98. Article 307 EC means that the obligations under these Conventions "shall not be affected by the provisions of this Treaty". This could be made explicit as regards specific Conventions of the ILO, as interpreted by the ILO's Freedom of Association Committee. ILO Convention 87 has been interpreted to include the right to strike. Rights under international labour law are not to be affected by the free movement provisions of the Treaty.

\section{c) Interpreting "proportionality” in light of international labour law}

The criterion used by the ECJ to assess the lawfulness of collective action is "proportionality". 59 This is not the standard used in international labour law, either by the Committee on Social Rights interpreting Article 6(4) of the European Social Charter (ESC) (which the Community is to be "having in mind" under Article 136 EC) or by the Freedom of Association Committee interpreting ILO Convention No. 87, ratified by all Member States (usually before accession to the EC, hence "shall not be affected" by the Treaty (Article 307 EC)).

The principles established under the ESC and ILO should be invoked to shape the criterion of "proportionality" invoked by the ECJ.

included 9 judges from the "old" Member States (Austria, Belgium, Denmark, Finland, Greece, Ireland, Luxembourg, Spain and the United Kingdom), and 4 judges from the "new" Member States (Estonia, Latvia, Lithuania, Poland). There was no judge from France, Germany or Italy. The juge rapporteur in Viking was from Luxembourg; the juge rapporteur in Laval was from Estonia. Submissions broadly supporting the employer in Viking were made to the ECJ by representatives of all 4 "new" Member States on the Court and the Czech Republic, Hungary, and the United Kingdom. Submissions broadly supporting the trade unions were made by representatives of 5 of the "old" Member States on the Court (Austria, Belgium, Denmark, Finland and Ireland), and France, Germany, Italy, Norway and Sweden.

59 In Viking, the standard is whether the threat to jobs and conditions is "serious" and the action is "suitable"; in Laval, the standard is that stipulated in the Posting Directive. 


\section{Conclusion}

\section{National labour law}

National labour law in the EU Member States emerged to redress the imbalance of power between employer and employee in national labour markets. It did this through two principal mechanisms: national legislation protecting employment and working conditions and national organisations of workers, trade unions, engaging in collective bargaining and collective action. 60

The labour law on national organisations of workers developed in the Member States through successive stages of repression, recognition and promotion. Although courts in the nineteenth century initially invoked legal doctrines protecting economic freedom to repress collective action by trade unions "in restraint of trade", ${ }^{61}$ legislative policy and judicial doctrine eventually recognised and even promoted the rights of workers and their organisations to collective bargaining and collective action.

\section{The balance of power in the EU economy}

The transnational economy of the European Union, like the national economies of the Member States, requires an economic balance of power between employers and workers. In the Member States, this balance is achieved, in part, through the collective action of trade unions and organisations of employers. The social partners at EU level have not achieved this balance of power.

EU law on free movement transforms the balance of economic power in the EU. The freedom of enterprises to move throughout the single European market has shifted the balance of economic power towards employers. This is particularly evident in the overwhelming economic power of multinational enterprises, the magnitude of transnational capital movements and the social dumping effects of global trade. The changing balance of economic power, together with competition over labour standards, weakens European economic integration and undermines support for the European political project.

60 B.A. Hepple (ed), The Making of Labour Law in Europe: A Comparative Study of Nine Countries up to 1945, London, Mansell, 1986.

61 An example is the British experience, see K.D. Ewing (ed), The Right to Strike: From the Trade Disputes Act 1906 to a Trade Union Freedom Bill 2006, Liverpool, The Institute of Employment Rights, 2007. 


\section{The law on workers' collective action}

One response to the shift in the economic balance of power resulting from the growth of the transnational economy is workers' traditional defence of collective action. As stated in the first sentence of this paper, a crucial element in maintaining a balance of economic power within Member States is the legal right to take collective action. National labour laws include the right to collective action. Though legal systems differ, no Member State outlaws collective action.

Under the pressure of EU law, Member States adapted their law to the requirements of free movement in the single market. The EU law of the common market transformed national rules governing the free movement of goods, services, capital or workers. However, national laws have not yet adapted to trade unions' response in the form of collective action which impacts on the transnational economy. ${ }^{62}$

\section{Transnational collective action and EU law}

Globalisation means that collective action frequently has an impact beyond national borders. National rules on collective action are inadequate to regulate transnational collective action having an impact on free movement in the EU. The decisions of the European Court of Justice in Laval, Viking and Rüffert, although not repressing collective action, indeed recognising it as a fundamental right, conspicuously failed to rise to the challenge of accommodating labour law doctrine to the new balance of power in a transnational European economy. ${ }^{63}$ Action on the European level is required to compensate for this failure.

62 B. Bercusson, "Foreword", to F. Dorssemont, T. Jespers, A. van Hoek (eds), Cross-Border Collective Actions in Europe: A Legal Challenge, Intersentia, Antwerp-Oxford, 2007.

63 I concluded my article of May 2007 in the European Law Journal on an earlier stage of this litigation by speculating that the future of the European trade union movement but also of the EU could be at stake. Now that the decisions have come out, it may be necessary to add the future of the European Court to this list... 
